\title{
INVESTIGATION OF PHARMACOGNOSTICAL, PHYTOCHEMICAL, AND PHARMACOLOGICAL ACTIVITY OF AERIAL ROOTS OF FICUS BENGHALENSIS LINN
}

\author{
KAMALIKA MAZUMDER ${ }^{1 *}$, HIMANGSHU S MAJI ${ }^{2}$, NRIPENDRA N BALA ${ }^{3}$ \\ ${ }^{1}$ Department of Pharmaceutical Chemistry, BCDA College of Pharmacy and Technology, Kolkata, West Bengal, India. ${ }^{2}$ Department of \\ Pharmaceutical technology, JIS University, Agarpara, Kolkata, West Bengal, India. ${ }^{3}$ Department of Pharmaceutics, BCDA College of \\ Pharmacy and Technology, Kolkata, West Bengal, India. Email: kamalika.payel@gmail.com
}

Received: 14 May 2018, Revised and Accepted: 18 June 2018

ABSTRACT

Objective: Ficus benghalensis Linn. (Moraceae family) is commonly known as banyan tree in English, which is used traditionally in India. The literature survey showed that the aerial roots of this plant are yet to be explored. Our main interest is to evaluate its pharmacognostic and phytochemical character by the standard monograph and to explore its in vitro antioxidant and in vivo analgesic activity study with ethyl acetate extract.

Methods: Pharmacognostic evaluation and phytochemical screening have been done using standard monograph. An in vitro antioxidant activity using ethyl acetate extract has been done using four different methods. In vivo analgesic activity of the ethyl acetate extract has been evaluated by acetic acid-induced writhing test in mice and tail flick method.

Results: Aerial roots of $F$. benghalensis have been found the rich source of steroidal glycosides, cardiac glycosides, flavonoids, tri-terpenoids, and phenols. The presence of phellem, phellogen, xylem, and phloem has been found after microscopic investigation. All the pharmacognostic parameters proved its purity. Results showed the absence of heavy metals. The ethyl acetate extract has shown potent antioxidant activity at $100 \mu \mathrm{g} / \mathrm{ml}$ concentration and higher analgesic activity at the concentration of $400 \mathrm{mg} / \mathrm{kg}$ than $200 \mathrm{mg} / \mathrm{kg}$.

Conclusion: Pharmacognostic characteristics and phytochemical properties revealed in this study could be used for the pharmacopoeial standard. Ethyl acetate extract showed potent antioxidant and analgesic activity.

Keywords: Antioxidant, Analgesic, Glycoside, Terpenoid, Pharmacognostic.

(c) 2018 The Authors. Published by Innovare Academic Sciences Pvt Ltd. This is an open access article under the CC BY license (http://creativecommons. org/licenses/by/4. 0/) DOI: http://dx.doi.org/10.22159/ajpcr.2018.v11i10.27287

\section{INTRODUCTION}

Nature has been a source of medicinal agents for thousands of years. Even today, plant materials continue to play a major role in primary health care for therapeutic remedies in many developing countries. According to the World Health Organization (WHO), a major part of the traditional therapies involves the use of plant extracts or their active constituents. The world health organisation (WHO) estimated that about $80 \%$ of the populations living in the developing countries depended on traditional medicine for their primary health-care needs [1].

Our plant of interest Ficus benghalensis Linn. (Moraceae family) [2] is commonly known as banyan tree in English, "Bot" in Bengali, and "Bargad" in Hindi. It is a large deciduous tree with aerial roots distributed all over India from Sub-Himalayan region and in the forests of Deccan and South India. It is found throughout the year grows in evergreen $[3,4]$.

Different parts of banyan tree used as traditional medicine to get remedies from several ailments. The bark is useful in burning sensation, hemorrhages, diarrhea, dysentery, diabetes, ulcer, and skin diseases. The leaves are good for ulcers, leprosy, skin allergies, etc. The buds are used in diarrhea and dysentery. The latex is useful in rheumatism, hemorrhoids, inflammation, and skin diseases [5].

The present studies were undertaken to establish the pharmacognostic characteristics, phytochemical nature, in vitro antioxidant activity, and in vivo analgesic activity of aerial roots of $F$. benghalensis Linn.

\section{METHODS}

\section{Chemical used}

Folin-Ciocalteu, sodium carbonate, ethylenediaminetetraacetic acid (EDTA), hydrogen peroxide, and trichloroacetic acid (TCA) were purchased from Merck Specialist Pvt., Ltd., Mumbai, India. 1, 1-diphenyl-2-picrylhydrazyl (DPPH) and deoxyribose were purchased from Hi-Media Laboratories Pvt., Ltd., Mumbai, India. Ascorbic acid, thiobarbituric acid (TBA), and phenazine methosulfate (PMS) were procured from Loba Chemie Pvt., Ltd., Mumbai, India. Ferric chloride, potassium ferric cyanide and nitroblue tetrazolium (NBT), and butylated hydroxyanisole (BHA) were purchased from Sigma Chemical Co. Ltd., (St. Louis, MO, USA). Diclofenac was from Macleods and pentazocine was purchased from Sun Pharmaceutical Industries Ltd. All other chemicals and reagents were of analytical grade.

\section{Collection and authentication of plant material}

The aerial roots of banyan tree were collected from Amdanga, North 24 Parganas, West Bengal, India, in October-November. The plant materials were authenticated and herbarium was deposited to $(\mathrm{CNH} /$ Tech II/2015/9/245) Central National Herbarium, Botanical Survey of India, Howrah - 711103.

\section{Macroscopic characteristics}

Macroscopic characteristics identification of medicinal plant materials is based on its shape, size, surface, texture, fracture, color, and appearance of the cut surface. The collected cut pieces of aerial roots were $8-10 \mathrm{~cm}$ long and macroscopic characteristics were evaluated.

\section{Microscopic characteristics}

Fresh specimens of aerial roots of $F$. benghalensis were collected and washed thoroughly with the distilled water. Then, the samples were fixed in $2.5 \%$ glutaraldehyde. Freehand semi-thin transverse sections were done with the help of a razor. The sections were allowed to dehydrate by passing it from various gradations of ethanol starting from $30 \%$ to $100 \%$. After the dehydration, sections were mounted over 
a drop of DPX taken in a clean slide and directly observed under light microscope (LEICA DM750) under low magnification.

\section{Drying}

After collection, the aerial roots were washed with fresh water and shade dried at temperature $27^{\circ} \mathrm{C}-30^{\circ} \mathrm{C}$ for $5-7$ days. Fresh dried aerial roots were cut into small pieces $(2-3 \mathrm{~cm})$, grounded in a mechanical mill, and screened through $0.6-0.8 \mathrm{~mm}$ sized particle mesh. This powder was stored in an airtight container and used for further extraction.

\section{Physicochemical parameters}

Evaluation of physicochemical parameters such as total ash, water-soluble ash, acid-insoluble ash, loss on drying, and presence of heavy metals were detected as per the guidelines of IP [6]. The intensity of the color produced with the test solution matched with that produced with the standard solution. Water, alcohol, chloroform, and petroleum ether-soluble extractive values [7] were also determined.

\section{Extraction}

The powdered plant materials (1000 g) were macerated using methanol as solvent and subjected to a rotary evaporator for evaporation of the solvent. The extract was further fractionated using hexane and ethyl acetate.

\section{Phytochemical screening}

The extracts were subjected to preliminary phytochemical analysis for detection of fats and oils, flavonoid, alkaloid, glycoside, steroid, triterpenoid, saponin, tannin, protein, and carbohydrate as per standard procedures [8].

\section{Antioxidant activity study}

Ascorbic acid was selected and used as a standard for the all in vitro antioxidant activities. All the solutions were freshly prepared.

\section{Hydroxyl radical scavenging activity}

The hydroxyl radical scavenging activity was measured by following the method of Halliwell et al. [9], and it was slightly modified. To the extract of different concentrations $(10,25,50$, and $100 \mu \mathrm{g} / \mathrm{ml}), 0.1 \mathrm{ml}(104 \mu \mathrm{M})$ of EDTA, $0.01 \mathrm{ml}(100 \mu \mathrm{M})$ of $\mathrm{Fecl}_{3}, 0.1 \mathrm{ml}(1 \mathrm{mM})$ of $\mathrm{H}_{2} \mathrm{O}_{2}$, and $0.36 \mathrm{ml}(2.8$ $\mathrm{mM}$ ) of deoxyribose were mixed. The final volume was prepared $1 \mathrm{ml}$ with phosphate buffer (20 mM, pH - 7.4). The mixture was then incubated at $37^{\circ} \mathrm{C}$ for $1 \mathrm{~h}$. Then, $1.0 \mathrm{ml}$ portion of the incubated mixture was mixed with $1.0 \mathrm{ml}$ of $10 \%$ TCA, $1.0 \mathrm{ml}$ of $0.5 \%$ TBA (in $0.025 \mathrm{M} \mathrm{NaOH}$ containing $0.025 \% \mathrm{BHA}$ ) and heated at $95{ }^{\circ} \mathrm{C}$ on water bath for $15 \mathrm{~min}$ to develop the pink color, and the absorbance was measured at $532 \mathrm{~nm}$ against the blank sample using an ultraviolet (UV)-visible spectrophotometer (Shimadzu UV-1700). The hydroxyl radical scavenging activity of the extract was determined using the following equation:

Percentage inhibition $=(1-$ absorbance of test $/$ absorbance of control $) \times 100$

\section{Reductive activity}

To the $1 \mathrm{ml}$ ethyl acetate extract of different concentrations $(10,25$, 50 , and $100 \mu \mathrm{g} / \mathrm{ml}$ ), $2.5 \mathrm{ml}$ of $100 \mathrm{mM}$ phosphate buffer of $\mathrm{pH} 6.6$ and $2.5 \mathrm{ml}$ of $1 \%$ potassium ferricyanide solution were added. The mixture was incubated at $50^{\circ} \mathrm{C}$ for $20 \mathrm{~min}$ and $2.5 \mathrm{ml}$ of $10 \%$ TCA was added. It was centrifuged at $3000 \mathrm{rpm}$ for $10 \mathrm{~min}$. $2.5 \mathrm{ml}$ of the supernatant was mixed with $2.5 \mathrm{ml}$ of distilled water and $0.5 \mathrm{ml}$ of $0.1 \%$ ferric chloride. Then, the absorbance of the reaction mixture was measured spectroscopically at $700 \mathrm{~nm}$ against the blank sample using a UV-visible spectrophotometer [10]. Higher the absorbance of the test mixtures indicated higher reductive activity.

\section{Superoxide radical scavenging activity}

Superoxide radical scavenging activity was determined by mixing $1 \mathrm{ml}$ of NBT solution (156 $\mu \mathrm{M}$ NBT in $100 \mathrm{mM}$ phosphate buffer, $\mathrm{pH}$ 7.4), $1 \mathrm{ml} \mathrm{NADH}$ solution (468 $\mu \mathrm{M}$ in $100 \mathrm{mM}$ phosphate buffer, $\mathrm{pH} 7.4$ ), and $0.1 \mathrm{ml}$ of sample solution of different concentrations of extract $(10,25,50$, and $100 \mu \mathrm{g} / \mathrm{ml})$. To this mixture, $100 \mu \mathrm{l}$ of PMS solution (60 $\mu \mathrm{M}$ PMS in $100 \mathrm{mM}$ phosphate buffer, $\mathrm{pH}$ 7.4) was added. The reaction mixture was then incubated at $25^{\circ} \mathrm{C}$ for $5 \mathrm{~min}$, and the absorbance was measured at $560 \mathrm{~nm}$ against the blank sample using a UV-visible spectrophotometer [11]. Lower the absorbance of the test mixtures indicated higher superoxide radical scavenging activity.

Superoxide radical scavenging effect $(\%)=(1-$ absorbance of test $/$ absorbance of control) $\times 100$

\section{DPPH radical scavenging activity}

$1 \mathrm{ml}$ of $0.1 \mathrm{mM}$ methanolic solution of DPPH was added to $3 \mathrm{ml}$ of the extract of different concentrations $(10,25,50$, and $100 \mu \mathrm{g} / \mathrm{ml})$. After continuous shaking of the mixture, it is allowed to stand for $30 \mathrm{~min}$ at room temperature. Then, the absorbance was measured at $517 \mathrm{~nm}$ against the blank using UV-visible spectrophotometer. Decreased the absorbance values of the reaction mixture were indicated increased free radical scavenging activity [12]. DPPH radical scavenging capability was calculated using the following equation:

DPPH scavenging effect $(\%)=(1$-absorbance of test/absorbance of control) $\times 100$

$\mathbf{5 0 \%}$ inhibitory concentration $\left(\mathrm{IC}_{50}\right)$ value determination $\mathrm{IC}_{50}$ value of the standard and extract from DPPH radical, hydroxyl radical, and superoxide radical scavenging activity was calculated by interpolation from the linear regression analysis.

\section{Estimation of total phenolic content}

The total phenolic content of ethyl acetate extract was estimated by following the Folin-Ciocalteu method of Slinkard and Singleton [13]. $0.1 \mathrm{ml}(1000 \mu \mathrm{g})$ solution of the extract was taken in a volumetric flaskand diluted with distilled water up to $46 \mathrm{ml} .1 \mathrm{ml}$ of Folin-Ciocalteu reagent was added to it and mixed thoroughly. After $3 \mathrm{~min}, 3 \mathrm{ml}$ of $2 \% \mathrm{Na}_{2} \mathrm{CO}_{3}$ was added and the mixture was allowed to stand for $2 \mathrm{~h}$ with random shaking. The absorbance was measured at $760 \mathrm{~nm}$. Pyrocatechol was taken as standard. The concentration of total phenolic contents within the extract estimated as equivalent to the microgram of pyrocatechol by the following equation obtained from standard pyrocatechol graph.

Absorbance $=0.001 *$ concentration of pyrocatechol $(\mu \mathrm{g})+0.0033[14]$.

\section{Analgesic activity study}

All the animals (albino mice) of 25-30 g wt were obtained from animal house of BCDA College of Pharmacy and Technology, Barasat. The animals were kept under standard laboratory conditions at room temperature with normal humidity. They were given standard diet and water ad libitum. The animals have fasted for $12 \mathrm{~h}$ with the availability of normal water before the experiment. The animals were divided into four groups $(n=6)$, control, standard, test 1 , and test 2 (two different concentrations of ethyl acetate extract). All the procedures for this in vivo analgesic activity study were approved by the institutional animal ethical committee with approval no BCDA/CPT/IAEC/02/2014-2015.

\section{Acetic acid-induced writhing test}

All the animals from the control group were treated with acetic acid $1 \% \mathrm{v} / \mathrm{v}$ solution. Second, third, and fourth groups are treated with standard drug solution diclofenac sodium $10 \mathrm{mg} / \mathrm{kg}$, ethyl acetate extract $200 \mathrm{mg} / \mathrm{kg}$, and ethyl acetate extract $400 \mathrm{mg} / \mathrm{kg}$, respectively, and also administered acetic acid to all the animals of three groups $15 \mathrm{~min}$ after the standard and test treatment [15]. Note the onset of writhing and calculate the percentage inhibition of writhing response compared with control group.

$\%$ inhibition of writhing = (1-no of writhing of test $/$ no of writhing of control)*100

\section{Tail flick method}

Basal reaction time (tail withdrawal time) to radiant heat was noted by placing the tail end $(2 \mathrm{~cm})$ of mice to the radiant heat source using 
analgesiometer. A cutoff time of $15 \mathrm{~s}$ is maintained. The four groups were treated with carboxymethyl cellulose (CMC) $0.5 \% \mathrm{w} / \mathrm{v}$, standard pentazocine $30 \mathrm{mg} / \mathrm{kg}$, ethyl acetate extract $200 \mathrm{mg} / \mathrm{kg}$, and ethyl acetate extract $400 \mathrm{mg} / \mathrm{kg}$, respectively, and noted the reaction time at $30,60,90$, and 120 min after the drug administration [16].

\section{Statistical analysis}

All the statistical analyses were done using Microsoft Office Excel 2007. Statistical significance was calculated by paired t-test.

\section{RESULTS}

\section{Pharmacognostic investigation}

The value of loss on drying is $3.62 \%$, the alcohol-soluble extractive value is $7.4 \%$, water-soluble extractive value is $12 \%$, the chloroformsoluble extractive value is $11.1 \%$, and the ether-soluble extractive value is $7.6 \%$. Total ash value is $3.32 \%$, acid-insoluble ash is $2.71 \%$, and the water-soluble ash value is $2.92 \%$. The limit test of heavy metals showed less intense color than standard solution, so it could be inferred that heavy metal is absent.

\section{Macroscopic character}

Cut pieces of aerial roots occurred in 8-10 cm long, $0.1-0.5 \mathrm{~cm}$ thick, cylindrical, unbranched, or branched. The external surface of the aerial root of $F$. benghalensis is gray, the cut surface is reddish-brown, rough due to longitudinal and transverse cracks and transverse rows of lenticels, fracture, and bark portion is fibrous, tough, and short in wood portion.

\section{Microscopic character}

Anatomy of the roots revealed a well-characterized secondary growth pattern. Outermost layer consists of bark followed by the phellem and phellogen. The structure of primary vascular bundle in this stage was revealed by the radially arranged exarch primary xylem located in the central region. The strands of secondary vascular tissues were arranged collaterally. Cambial activity causes the formation of medullary rays which runs between the xylem and the phloem through the cambium. Xylem vessel shows almost circular in outline. Overall, the anatomical structures revealed the picture of a typical dicot root showing a secondary growth. No other kind of special character, as well as an anomaly, was observed. The present anatomical study was predictable to conclude that in this case there is hardly any change in their anatomical structures and cellular pattern in relation to their metabolic and chemical profile.

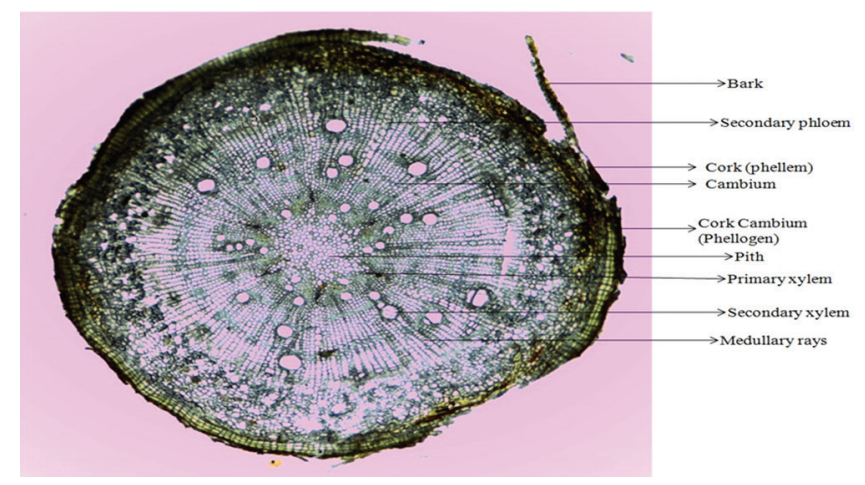

Phytochemical investigations

The N-hexane extract of aerial roots of $F$ benghalensis Linn. has shown the presence of saponin, triterpenoid, fats, and oils. Ethyl acetate and methanol extract showed the presence of flavonoid, saponin, steroid, triterpenoids, glycosides, tannins, and phenols. The presence of alkaloid was observed only in the methanolic extract. Carbohydrate and protein were absent.

\section{Total phenolic content}

$1 \mathrm{mg}$ of each concentration of the ethyl acetate extract contained $36.66 \pm 0.05 \mu \mathrm{g}$ of pyrocatechol equivalents of phenols.

\section{Antioxidant activity}

\section{Hydroxyl radical scavenging activity}

The extracts have shown Hydroxyl radical scavenging activity in the dosedependent manner which is expressed as the percentage of inhibition (Fig. 1). About $73.49 \pm 8.93 \%$ of the Hydroxyl radical scavenging activity was observed in case of the extracts at $100 \mu \mathrm{g} / \mathrm{mL}$. The percentages of inhibition of hydroxyl scavenging activity of extract in different concentrations are lower than standard $(98.83 \pm 5.85 \%)$ but are significant statistically.

\section{Reductive activity}

The extract showed the increased reducing power activity with the increment of dose. It has shown a significant and highest reducing power activity (optical density 0.304 ) at highest dose of $100 \mu \mathrm{g} / \mathrm{ml}$ which is lower than standard (0.351 \pm 0.009$)$ (Fig. 2).

\section{Superoxide radical scavenging activity}

Ethyl acetate extract showed significant superoxide radical scavenging property at the highest concentration $(100 \mu \mathrm{g} / \mathrm{ml})$. It has shown about $54.83 \pm 0.73 \%$ of superoxide radical scavenging (Fig. 3 ) activity, whereas standard showed $71.65 \pm 1.43 \%$ of superoxide radical scavenging property. The extract showed the dose-dependent activity.

\section{DPPH radical scavenging activity}

The ethyl acetate extract showed highest antioxidant property in DPPH radical scavenging method. The extract showed a dose-dependent inhibition of DPPH radical. At dose of $100 \mu \mathrm{g} / \mathrm{mL}$, extract showed nearly $83.90 \pm 2.6 \%$ of inhibition which significant and close to the activity shown by the standard drug $(91.37 \pm 1.23)$ (Fig. 4).

All statistically analyzed data are expressed as mean \pm standard deviation $(n=6)$. Statistical significance $(p)$ calculated by paired t-test. $\mathrm{p}<0.05$ considered to be statistically significant.

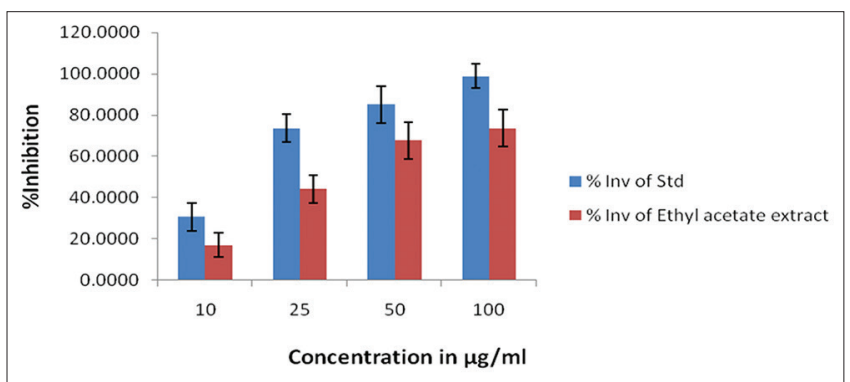

Fig. 1: Hydroxyl radical scavenging activity of different concentrations of std. (standard ascorbic acid) and ethyl acetate extract. Values are expressed as mean \pm standard deviation where $\mathrm{n}=6$. All data are statistically significant at $\mathbf{p}<0.05$

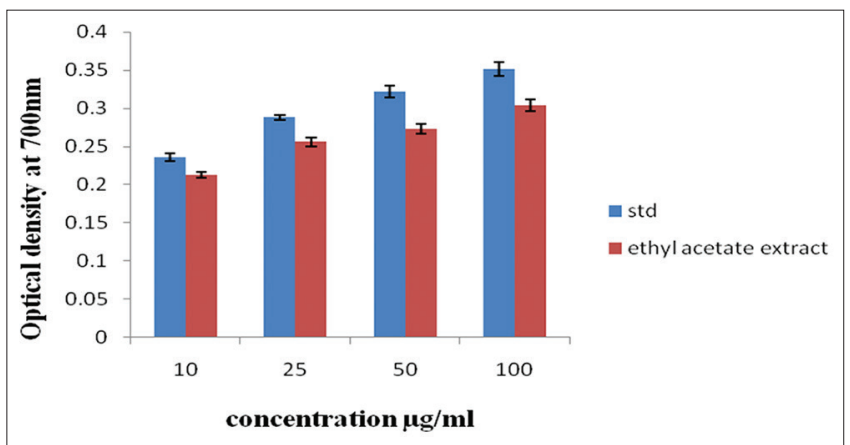

Fig. 2: Reductive activity of different concentrations of std. (standard ascorbic acid) and ethyl acetate extract. Each point represents mean \pm standard deviation where $n=6$. All data are statistically significant at $\mathbf{p}<0.05$ 


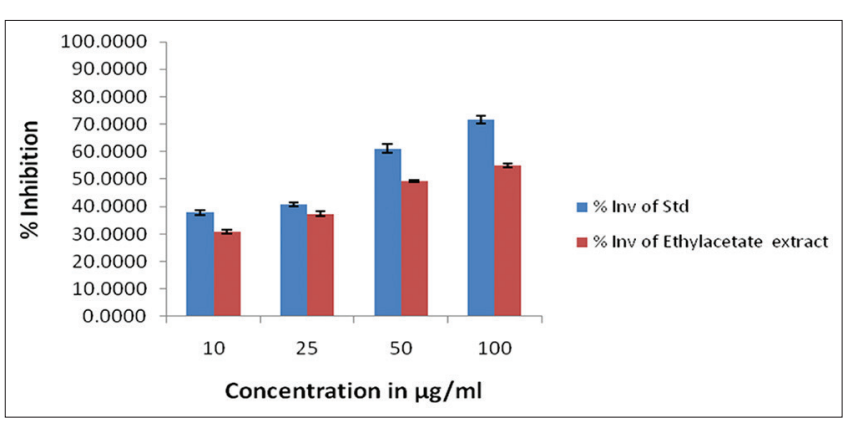

Fig. 3: Superoxide radical scavenging activity of different concentrations of std. (standard ascorbic acid) and ethyl acetate extract. Each point represents mean \pm standard deviation where $\mathrm{n}=6$. All data are statistically significant at $\mathbf{p}<0.05$

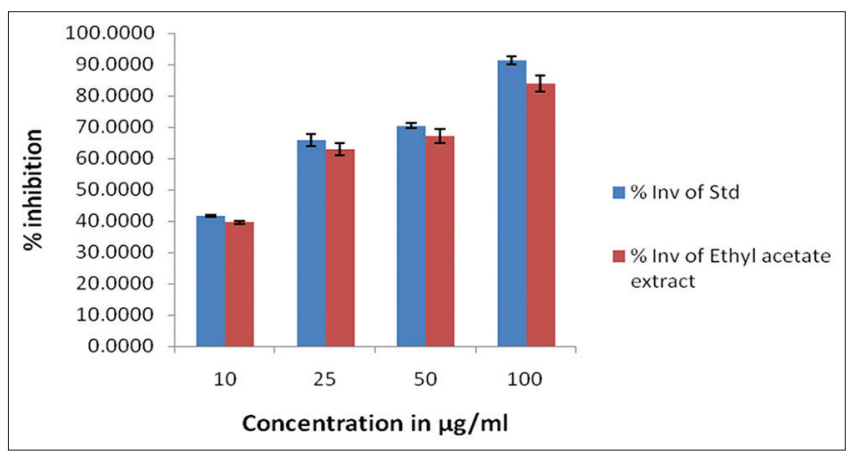

Fig. 4: 1, 1-diphenyl-2-picrylhydrazyl radical scavenging activity of different concentrations of std. (standard ascorbic acid) and ethyl acetate extract. Values are expressed as mean \pm standard deviation where $n=6$. All data are statistically significant at $p<0.05$

IC ${ }_{50}$ value

In hydroxyl radical scavenging ability method, the results showed that the $\mathrm{IC}_{50}$ value of standard and ethyl acetate extract was $11.53 \mu \mathrm{g} / \mathrm{ml}$ and $45.25 \mu \mathrm{g} / \mathrm{ml}$, respectively. In superoxide radical scavenging method, the results showed that the $\mathrm{IC}_{50}$ value of standard and ethyl acetate extract was $39.18 \mu \mathrm{g} / \mathrm{ml}$ and $72.75 \mu \mathrm{g} / \mathrm{ml}$, respectively. In DPPH radicals scavenging method, the results showed that the $\mathrm{IC}_{50}$ value of standard and ethyl acetate extract was $10.57 \mu \mathrm{g} / \mathrm{ml}$ and $14.75 \mu \mathrm{g} / \mathrm{ml}$, respectively.

\section{Acetic acid-induced writhing test}

Ethyl acetate extract showed $39.33 \pm 0.75 \%$ and $60 \pm 0.63 \%$ inhibition of writhing at $200 \mathrm{mg} / \mathrm{ml}$ and $400 \mathrm{mg} / \mathrm{ml}$ concentration, respectively, and diclofenac sodium showed $66.67 \pm 0.52 \%$ inhibition. Results showed that the inhibitory effect of diclofenac sodium was more than the extract, but all the data are statistically significant at $p<0.001$ when compared with control (Fig. 5).

\section{Tail flick method}

Results showed that normal CMC (0.5\%)-treated group (control) did not show any significant difference in the reaction time on tail flick up to $120 \mathrm{~min}$ of observation. Pentazocine (30 mg/kg)-treated group (standard) showed maximum reaction time of $13.2 \pm 0.3 \mathrm{~s}$ at $90 \mathrm{~min}$, but the response is lowered when observed at $120 \mathrm{~min}$. Ethyl acetate extract of $200 \mathrm{mg} / \mathrm{kg}$ body weight and $400 \mathrm{mg} / \mathrm{kg}$ body weight showed maximum reaction time of $7.2 \pm 0.33 \mathrm{~s}$ and $10.03 \pm 0.5 \mathrm{~s}$, respectively, at $90 \mathrm{~min}$ and the response is lowered at $120 \mathrm{~min}$. All the values are statistically significant when compared with the control at $\mathrm{p}<0.001$ and $<0.002$ (Fig. 6).

\section{DISCUSSION}

The pharmacognostic parameters (Table 1) of a crude drug are important to establish its proper identity. The microscopic character

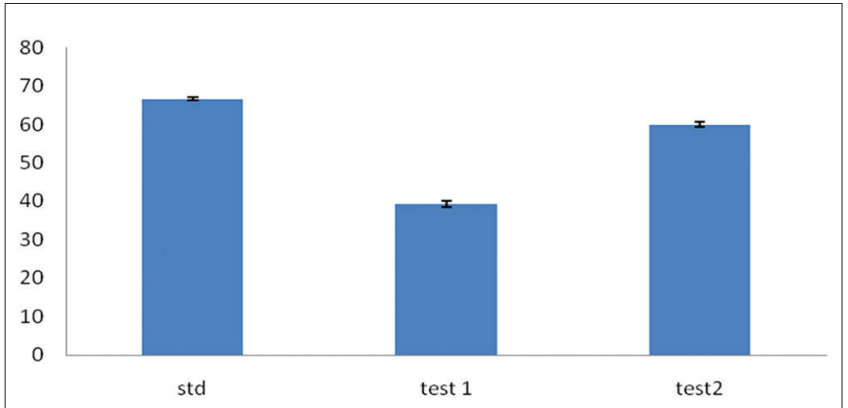

Fig. 5: Percentage inhibition of writhing after administration of std. (diclofenac), test 1 (ethyl acetate extract $200 \mathrm{mg} / \mathrm{kg}$ ), test 2 (ethyl acetate extract $400 \mathrm{mg} / \mathrm{kg}$ ). Values are expressed as mean \pm standard deviation where $n=6$. All data are statistically significant at $\mathrm{p}<0.001$

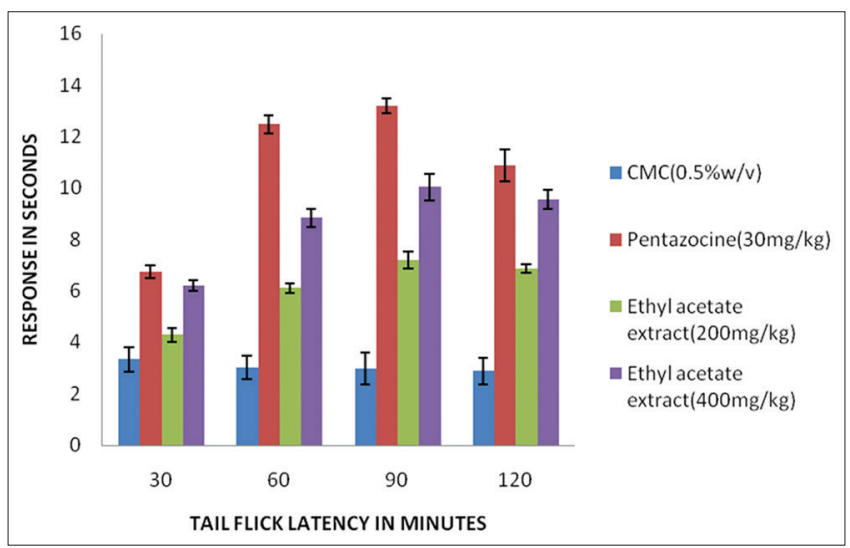

Fig. 6: Measurement of tail flick response after administration of control carboxymethyl cellulose, std., pentazocine, ethyl acetate extract $200 \mathrm{mg} / \mathrm{kg}$, ethyl acetate extract $400 \mathrm{mg} / \mathrm{kg}$. Values are expressed as mean \pm standard deviation where $n=6$. All data are statistically significant at $\mathbf{p}<0.001$ and $<0.002$

has shown the presence of phellem, phellogen, xylem, phloem, and medullary rays. All the physicochemical parameters such as loss on drying $(3.62 \%)$, total ash value $(3.32 \%)$, acid-insoluble ash value $(2.71 \%)$, water-soluble ash value $(2.92 \%)$, alcohol-soluble extractive value $(7.4 \%)$, water-soluble extractive value $(12 \%)$, chloroform-soluble extractive value $(11.1 \%)$, and ether-soluble extractive value $(7.6 \%)$ helped to prove its botanical quality. The presence of heavy metal is not found by limit test. It proved the safety of the use of the crude drug. Presences of phytoconstituents are summarized in Table 2. N-hexane extract of aerial root of $F$. benghalensis Linn. showed the presence of fats and oils and triterpenoid. Methanolic extract showed the presence of alkaloid. Ethyl acetate extract and methanolic extract have shown the presence of flavonoids, phenols, steroids, and triterpenoid in an affluent amount. Ethyl acetate extract was selected for the determination of biological activity.

\section{Hydroxyl radical scavenging ability}

Hydroxyl radical is a potential reactive oxygen species for the biological system. It can cause damage to the cell by reacting with the polyunsaturated fatty acid of cell membrane phospholipids. Hydroxyl radical on reaction to the cell can lead to carcinogenesis, mutagenesis, and cytotoxicity [17]. An iron EDTA chelate is incubated with deoxyribose in phosphate buffer at $\mathrm{pH} 7.4$, the formation of $\mathrm{OH}$ radicals occurred. It reacted with deoxyribose and formed malondialdehyde (MDA). MDA reacted with TBA and formed pink chromogen, i.e. MDATBA adduct. The rate of degradation of deoxyribose is increased by the addition of an antioxidant. Hence, increased values of absorbance with 
Table 1: Preliminary pharmacognostic evaluation

\begin{tabular}{ll}
\hline Parameters & Values $(\% \mathbf{w} / \mathbf{w})$ \\
\hline Loss of drying & 3.62 \\
$\quad$ Extractive value & \\
Alcohol-soluble extractive & 7.4 \\
Water-soluble extractive & 12 \\
Chloroform-soluble extractive & 11.1 \\
Ether-soluble extractive & 7.6 \\
Ash value & \\
Total ash & 3.32 \\
Acid-insoluble ash & 2.71 \\
Water-soluble ash & 2.92 \\
Heavy metals & Absent (No turbidity shown) \\
\hline
\end{tabular}

Table 2: Phytochemical investigation

\begin{tabular}{llll}
\hline Phytochemical extract & $\begin{array}{l}\text { N-hexane } \\
\text { extract }\end{array}$ & $\begin{array}{l}\text { Ethyl acetate } \\
\text { extract }\end{array}$ & $\begin{array}{l}\text { Methanol } \\
\text { extract }\end{array}$ \\
\hline Alkaloid & - & - & + \\
Flavonoid & - & ++ & + \\
Saponin & + & + & + \\
Steroid & - & ++ & + \\
Cardiac glycoside & - & + & + \\
Fats and Oils & ++ & - & - \\
Tannin & - & + & + \\
Phenol & - & + & ++ \\
Triterpenoid & ++ & ++ & + \\
Carbohydrate & - & - & - \\
Proteins and amino acid & - & - & - \\
\hline
\end{tabular}

increased concentrations proved the antioxidant property of extract and standard. Fig. 1 shows a significant $(p<0.05)$ increase in hydroxyl radical scavenging ability with increased concentration of the standard $\left(98.83 \pm 5.85 \%\right.$ inhibition at $100 \mu \mathrm{g} / \mathrm{ml}$ concentration and $\mathrm{IC}_{50}$ value is $11.53 \mu \mathrm{g} / \mathrm{ml}$ ) and extract $(73.49 \pm 8.93 \%$ inhibition at $100 \mu \mathrm{g} / \mathrm{ml}$ concentration and $\mathrm{IC}_{50}$ value is $45.25 \mu \mathrm{g} / \mathrm{ml}$ ).

\section{Effect on reductive ability}

The reducing power activity of the extract is a significant indicator of the antioxidant property. This property measured by the ability of the extracts to convert $\mathrm{Fe} 3+$ to $\mathrm{Fe} 2+$ and by the donation of an electron [18]. The reducing power of a compound is a significant indicator of its potential antioxidant activity. The reducing power of extracts increased with increasing concentration of samples. Fig. 2 shows a significant $(p<0.05)$ increase in reducing ability with increased concentration of the standard (optical density $0.351 \pm 0.009$ at $100 \mu \mathrm{g} / \mathrm{ml}$ concentration) and extract (optical density $0.304 \pm 0.008$ at $100 \mu \mathrm{g} / \mathrm{ml}$ concentration).

\section{Effects on superoxide anion radical scavenging activity}

Superoxide radical is a biological source of reactive oxygen species. It is responsible for the production of hydroxyl radicals and oxygen free radical. These free radicals are causing oxidative stress [19]. In the PMS-NADH-NBT system, superoxide anion from dissolved oxygen from the coupling reaction of PMS-NADH reduces NBT. The decrease in absorbance at $560 \mathrm{~nm}$ with antioxidants indicates the consumption of superoxide anion in the reaction mixtures, Fig. 3 shows a significant $(\mathrm{p}<0.05)$ increase in superoxide radical scavenging ability with increased concentration of the standard $(71.65 \pm 1.43 \%$ inhibition at $100 \mu \mathrm{g} / \mathrm{ml}$ concentration and $\mathrm{IC}_{50}$ value is $39.18 \mu \mathrm{g} / \mathrm{ml}$ ) and extract $\left(54.83 \pm 0.73 \%\right.$ inhibition at $100 \mu \mathrm{g} / \mathrm{ml}$ concentration and $\mathrm{IC}_{50}$ value is $72.75 \mu \mathrm{g} / \mathrm{ml}$ ).

\section{The DPPH radical scavenging activity}

This model is widely used to evaluate free radical scavenging activity. DPPH is a stable free radical that accepts an electron or hydrogen radical to become a stable diamagnetic molecule [20]. The absorption maximum of a stable DPPH radical in methanol was $517 \mathrm{~nm}$ [21]. The decrease in absorbance of DPPH radical caused by antioxidants because of the reaction between antioxidant molecules and radical progressed, results in the scavenging of the radicals by hydrogen donation. It is visually noticeable that as a change in color from purple to yellow. Based on the data obtained from this study, ethyl acetate extract was effective free radical scavenger that reacts with free radicals and acts as a primary antioxidant. Fig. 4 shows a significant $(\mathrm{p}<0.05)$ DPPH radicals scavenging ability of the standard $(91.36 \pm 1.24 \%$ inhibition at $100 \mu \mathrm{g} / \mathrm{ml}$ concentration and $\mathrm{IC}_{50}$ value is $10.57 \mu \mathrm{g} / \mathrm{ml}$ ) and extract $\left(83.96 \pm 2.95 \%\right.$ inhibition at $100 \mu \mathrm{g} / \mathrm{ml}$ concentration and $\mathrm{IC}_{50}$ value is $14.75 \mu \mathrm{g} / \mathrm{ml})$.

\section{Acetic acid-induced writhing reflex}

This method was done to evaluate the peripheral analgesic effect of the extract. The pain sensation is due to the production of prostaglandin through cyclooxygenase pathway. Diclofenac sodium and the extract may be acted by inhibition of cyclooxygenase pathway [22].

\section{Tail flick method}

This method was done to evaluate central Analgesic activity of the extract. The results showed that there was a significant time-dependent initial increase (from $30 \mathrm{~min}$ to $90 \mathrm{~min}$ ) and then gradual decrease (at $120 \mathrm{~min}$ ) in the tail flick time of mice compared to control. This may be due to the agonist-antagonist action of pentazocine on opioid receptors [23]. The ethyl acetate extract showed its potent analgesic activity may be by acting on opioid receptors.

\section{CONCLUSION}

The present study proved that the ethyl acetate extract of aerial roots of $F$. benghalensis Linn. exhibited significant antioxidant potential with increased concentration and significant analgesic activity which is most effective at higher concentration. The ethyl acetate extract showed high total phenolic content and the phytochemicals which are present in the extract are important sources of antioxidants. Further studies will be carried out to explore the bioactive molecules responsible for the antioxidant and analgesic activity.

\section{ACKNOWLEDGMENT}

The authors are thankful to Mr. Sandeep Chakraborty, Asst. Prof. Department of Botany, Achhruram Memorial College, Purulia, for his help to the study.

\section{AUTHOR'S CONTRIBUTION}

Mrs. Kamalika Mazumder has performed all the experiments and prepared the manuscript. Dr. Himangshu S. Maji and Dr. Nripendranath Bala helped in choosing the experimental protocols and manuscript correction.

\section{CONFLICTS OF INTEREST}

All the authors declare that there are no conflicts of interest.

\section{REFERENCES}

1. Ekor M. The growing use of herbal medicines: Issues relating to adverse reactions and challenges in monitoring safety. Front Pharmacol 2014;4:177.

2. Govindan V, Francis GS. Qualitative and quantitative determination of secondary metabolites and antioxidant potential of Ficus benghalensis Linn seed. Int J Pharm Pharm Sci 2015;7:118-24.

3. Gayathri M, Kannabiran K. Antidiabetic and ameliorative potential of Ficus bengalensis bark extract in streptozotocin induced diabetic rats. Indian J Clin Biochem 2008;23:394-400.

4. Patil VV, Patil VR. Ficus Bengalensis Linn.-an overview. Int J Pharma Bio Sci 2010;1:1-11.

5. Patel MA, Patel PK, Patel MB. Aqueous extract of Ficus bengalensis Linn. Bark for inflammatory bowel disease. J.young pharm 2010;2:130-6.

6. Indian pharmacopoeia. Vol. 1.The Indian Pharmacopoeial Commission. Ghaziabad: Chemical Methods; 2014. p. 96-9.

7. Kokate CK. Practical Pharmacognosy. Evaluation of Crude Drug. $4^{\text {th }}$ ed. New Delhi, India: Vallabh Prakashan; 1994. p. 124-5. 
8. Kokate CK. Practical Pharmacognosy. Phytochemical Screening. $4^{\text {th }}$ ed. New Delhi, India: Vallabh Prakashan; 1994. p. 108-9.

9. Halliwell B, Gutteridge JM, Aruoma OI. The deoxyribose method: A simple "test-tube" assay for determination of rate constants for reactions of hydroxyl radicals. Anal Biochem 1987;1:215-9.

10. Siddhuraju P, Becker K. Antioxidant properties of various solvent extracts of total phenolic constituents from three different agroclimatic origins of drumstick tree (Moringa oleifera Lam.) Leaves. J Agric Food Chem 2003;51:2144-55.

11. Chaudhary A, Bhandari A, Pandurangan A. Superoxide radical scavenging activity antioxidant potential and total phenolic content of methanolic bark extract of Madhuca indica (koenig) Gmelin. Anc sci life 2012;31:132-6.

12. Biswas M, Halder PK, Ghosh AK. Antioxidant and free-radicalscavenging effects of fruits of Dregea volubilis. J Nat Sci Biol Med 2010;1:29-34.

13. Slinkard K, Singleton VL. Total phenol analysis: Automation and comparison with manual methods. Am J Enol Vitic 1977;28:49-55.

14. Gulcin I, Oktay M, Kufrevioglu I. Determination of antioxidant activity of Lichen Cetraria islandica (L). Ach J Ethnopharmacol 2002:79·325-9.

15. Afsar T, Khan M.R, Razak S, Ullah S, Mirza B. Antipyretic, antiinflammatory and analgesic activity of Acacia Hydaspica R. Parker and its phytochemical analysis. BMC Complement Altern Med 2015;15:136-47.
16. Banarjee S, Mukherjee A, Chatterjee TK. Evaluation of analgesic activities of methanolic extract of medicinal plant Juniperus communis Linn. Int J Pharm Sci 2012;4:547-50.

17. Saeed N, Khan M.R, Shabbir M. Antioxidant activity, total phenolic and total flavonoid contents of whole plant extracts Torilis leptophylla $\mathrm{L}$. BMC Complement Altern Med 2012;12:221-33.

18. Gordon $\mathrm{MH}$. The mechanism of antioxidant action in vitro. In Food antioxidants. In: Hudson BJ, editor. London: Elsevier Applied Science; 1990. p. 1-18.

19. Meyer AS, Isaksen A. Application of enzymes as food antioxidants. Trends Food Sci Tech 1995;6:300-4

20. Kasthuri O R, Ramesh B. Phytochemical screening and in vitro antioxidant activities of leaf extracts of Alternanthera brasiliana (L). Kuntze and Alternanthera bettzickiana Regel. Asian J Pharm Clin Res 2018;11:266-72.

21. Zahin M, Aqil F, Ahmad I. The in vitro antioxidant activity and total phenolic content of four Indian medicinal plants. Int J Pharm Pharm Sci 2009; 1:88-95.

22. Duarte I, Nakamura M, Ferreira S. Participation of the sympathetic system in acetic acid-induced writhing in mice. Braz J Med Biol Res 1987;21:341-3.

23. Sethi N, Bhatti R, Ishar MPS. In vivo pharmacological profile of substituted (3-pyridyl)-2-phenylisoxazolidine analogues of nicotine as novel antinociceptives. Res Pharm Sci 2014;9:59-67. 